\title{
Effect of cadmium on growth, micronutrient concentration, and $\delta$-aminolevulinic acid dehydratase and acid phosphatase activities in plants of Pfaffia glomerata
}

\section{Etiane C. Skrebsky ${ }^{1,3}$, Luciane A. Tabaldi ${ }^{1,3}$, Luciane B. Pereira ${ }^{2,4}$, Renata Rauber ${ }^{1,}$, Joseila Maldaner ${ }^{1,3}$, Denise Cargnelutti ${ }^{2,4}$, Jamile F. Gonçalves ${ }^{1,3}$, Gabriel Y. Castro ${ }^{1}$, Maria R.C. Shetinger ${ }^{2,5^{*}}$ and Fernando T. Nicoloso $0^{1,3^{* *}}$}

\author{
${ }^{1}$ Departamento de Biologia. \\ ${ }^{2}$ Departamento de Química. \\ ${ }^{3}$ Programa de Pós-Graduação em Agronomia. \\ ${ }^{4}$ Programa de Pós-Graduação em Bioquímica Toxicologia. Centro de Ciências Naturais e Exatas, Universidade \\ Federal de Santa Maria, 97105-900, Santa Maria, RS, Brasil. \\ *, ${ }^{* *}$ Corresponding authors: mariashetinger@gmail.com and ftnicoloso@yahoo.com. \\ Received: 05 April 2008; Returned for revision: 17 December 2008; Accepted: 20 Febrary 2009
}

Pfaffia glomerata (Spreng.) Pedersen plantlets were grown under different cadmium (Cd) concentrations $(0,20,40,60$ and $80 \mu \mathrm{M})$ in a hydroponic system during $7 \mathrm{~d}$. Plant growth, micronutrient, chlorophyll and carotenoid concentrations, as well as $\delta$-aminolevulinic acid dehydratase (ALA-D; E.C.4.2.1.24) and acid phosphatase (AP; E.C.3.1.3.2) activities were analysed. Cadmium concentration in both shoots and roots increased with increasing external $\mathrm{Cd}$ levels. Metal concentration in roots were on average 12-fold higher than in shoot tissues. Root length was unaffected by $\mathrm{Cd}$ treatments. In contrast, dry weight of both shoot and roots increased significantly after exposure to 20 and $40 \mu \mathrm{M} \mathrm{Cd}$. Additionally, shoot and total plant dry weight were only reduced in plants exposed to $80 \mu \mathrm{M} \mathrm{Cd}$. In contrast, root dry weight decreased significantly after exposure with $\mathrm{Cd}$ concentrations above $40 \mu \mathrm{M}$. A micronutrient- and organdependent response to $\mathrm{Cd}$ toxicity was observed. Zinc and Cu concentrations in both, shoot and roots did not alter due to exposure to $\mathrm{Cd}$. Cadmium stress reduced $\mathrm{Mn}$ uptake but not its translocation within the plant. A synergistic effect of $\mathrm{Cd}$ on Fe concentration in root at $20 \mu \mathrm{M}$ and $80 \mu \mathrm{M}$ Cd levels was observed. The activity of AP, and especially that of ALA-D, was reduced with increasing Cd levels. At these $\mathrm{Cd}$ levels, the chlorophyll concentration was also reduced. There was a positive correlation between concentrations of carotenoids and chlorophylls. Our results indicate that $P$. glomerata seems to have some degree of $\mathrm{Cd}$ tolerance.

Key Words: Brazilian ginseng, carotenoid, chlorophyll, heavy metal, micronutrient, phytoremediation

Efeito do cádmio no crescimento, concentração de micronutrientes e atividades da desidratase do ácido $\delta$-aminolevulínico (ALA-D) e fosfatase ácida (AP) em plantas de Pfaffia glomerata: Plântulas de Pfaffia glomerata (Spreng.) Pedersen foram cultivadas em cinco níveis $(0,20,40,60$ e $80 \mu \mathrm{M})$ de cádmio (Cd) em um sistema hidropônico durante 7 d, visando-se analisar 0 crescimento, as concentrações de micronutrientes, clorofilas e carotenóides, bem como as atividades da desidratase do ácido ס-aminolevulínico (ALA-D; E.C.4.2.1.24) e fosfatase ácida (AP; E.C.3.1.3.2) nas plantas. A concentração de Cd, na parte aérea e raízes, aumentou com o incremento dos níveis de $\mathrm{Cd}$. A concentração de $\mathrm{Cd}$ nas raízes foi, em média, 12 vezes maior do que na 
parte aérea. 0 comprimento das raízes não foi afetado pelos tratamentos de $\mathrm{Cd}$. Em contraste, a biomassa seca da parte aérea e raízes aumentou significativamente pela adição de 20 e $40 \mu \mathrm{M}$ Cd. Além disso, a biomassa seca total das plantas somente diminuiu no nível de $80 \mu \mathrm{M} \mathrm{Cd}$ em relação à das plantas-controle. Por outro lado, a biomassa radicular diminuiu significativamente pela adição de $\mathrm{Cd}$ a níveis superiores a $40 \mu \mathrm{M}$. Constatou-se resposta dependente do órgão e do micronutriente à toxicidade de $\mathrm{Cd}$. As concentrações de $\mathrm{Zn}$ e Cu na parte aérea e raízes não foram alteradas pela presença de $\mathrm{Cd}$. A absorção de $\mathrm{Mn}$ foi diminuída pelo estresse de $\mathrm{Cd}$, porém sua translocação não foi alterada. Um efeito sinergístico do $\mathrm{Cd}$ na concentração de Fe nas raízes foi observado nos níveis de 20 e $80 \mu \mathrm{M}$ Cd. As atividades da ALA-D e AP foram diminuídas com o incremento dos níveis de Cd, porém a ALA-D foi mais afetada. Naquelas concentrações de Cd, a concentração de clorofila também foi diminuída. Houve uma correlação positiva entre as concentrações de carotenóides e clorofila. 0 s resultados indicam que a $P$. glomerata parece ter algum grau de tolerância ao $\mathrm{Cd}$.

Palavras-Chave: carotenóides, clorofilas, fitorremediação, ginseng brasileiro, micronutrientes, metal pesado.

\section{INTRODUCTION}

Heavy metal pollution is of considerable importance and relevant for the present situation of increasing levels of pollution and its obvious impact on human health through the food chain (Hadjiliadis, 1997; Almeida et al., 2007).

It is known that unfavourable effects of heavy metals on plants are manifested, e.g. by inhibiting the normal uptake and utilization of mineral nutrients (Jiang et al., 2004; Dong et al., 2006). Cadmium (Cd), for instance, can interfere with mineral nutrition by hampering the uptake and translocation of essential elements (Boussama et al., 1999; Jiang et al., 2004; Dong et al., 2006). Moreover, $\mathrm{Cd}$ can inhibit photosynthesis and plant growth (Gallego et al., 1996). Additionally, it affects the overall cell metabolism via alterations in (i) the behaviour of key enzymes of important pathways (Verma and Dubey, 2001), (ii) membrane composition and function (Fodor et al., 1995; Quariti et al., 1997) and (iii) by lowering the control of the cell redox state, that ultimately causes oxidative stress (Gratão et al., 2005). Acid phosphatases, AP (ortophosphoric-monoester phosphohydrolases; E.C.3.1.3.2) are widely distributed in plants and significantly differ in their susceptibility to be inhibited by various compounds (Penheiter et al., 1997). Acid phosphatases unspecifically catalyze the hydrolysis of a variety of phosphate esters in an acidic environment (Duff et al., 1994). These enzymes are proposed to act in the maintenance of the phosphorus status of the plant, particularly with respect to a role in accessing phosphorus from the soil (Duff et al., 1994). Several factors have been shown to influence the activity of AP (Duff et al., 1994), but the effects of heavy metals on AP are poorly understood (Tabaldi et al., 2007).
The enzyme $\delta$-aminolevulinic acid dehydratase (ALA-D; E.C.4.2.1.24), which catalyzes the asymmetric condensation of two molecules of $\delta$-aminolevulinic acid to porphobilinogen, is sensitive to metals due to its sulphydrylic nature (Pereira et al., 2006). The synthesis of porphobilinogen promotes the formation of porphyrins, hemes and chlorophylls, essential factors of an adequate aerobic metabolism and photosynthesis (Jaffe et al., 2000). Furthermore, altered ALA-D activity concomitant with reduced chlorophyll contents has been reported in many terrestrial plants exposed to various metals (Pereira et al., 2006).

The mechanism of action of heavy metals is due to their capability to form strong bonds with bases and phosphates of nucleic acids and with -SH groups of proteins, modifying both, their structure and function. They compete with other divalent cations such as $\mathrm{Ca}, \mathrm{Zn}$ and $\mathrm{Mg}$, replacing them, thus inhibiting their physiological roles (Pauza et al., 2005; Tabaldi et al., 2007).

The genus Pfaffia belongs to the Amaranthaceae family and has about 90 species distributed in Central and South America. In Brazil, 27 species have been described (Taniguchi et al., 1997). The roots of Pfaffia glomerata are of special interest due to their popular use as anti-tumoral, anti-diabetic and aphrodisiac tonic (Montanari et al., 1999). Due to the indications and the form of its roots, which are similar to the Asian ginseng, its common name is Brazilian ginseng (Montanari et al., 1999). In a recent study, Carneiro et al. (2002) showed that an undetermined species of the genus Pfaffia exhibited high tolerance to soil contamination, growing quite abundantly in a soil mix with 90 and $1,450 \mathrm{mg} \mathrm{kg}^{-1}$ of 
$\mathrm{Cd}$ and $\mathrm{Zn}$, respectively. In addition, this species showed a $\mathrm{Cd}$ content higher than $100 \mathrm{mg} \mathrm{kg}^{-1}$, thus being considered a Cd hyperacumulator. Perhaps it contributes to phytoremediation in areas with high contamination of heavy metals.

Taking into account these characteristics and the high commercial value of $P$. glomerata to the pharmaceutical industry, it is important to determine whether this species accumulates and is tolerant to $\mathrm{Cd}$. If there is a tolerance or an accumulation it is of interest, what mechanisms are involved. The present work was therefore designed to analyze the growth, micronutrient, chlorophyll and carotenoid concentrations, as well as ALA-D and acid phosphatase activities in Pfaffia glomerata (Spreng.) Pedersen plantlets during an extended 7-d period of exposure to different $\mathrm{Cd}$ concentrations.

\section{MATERIAL AND METHODS}

Experimental design: Tissue culture plantlets of $P$. glomerata (accession JB/UFSM) were obtained from the Ginseng Germplasm program, Universidade Federal de Santa Maria, State of Rio Grande do Sul, Brazil. Nodal segments $(1.0 \mathrm{~cm}$ long) were micropropagated in Murashige and Skoog (1962) medium, supplemented with $30 \mathrm{~g} \mathrm{~L}^{-1}$ of sucrose, $0.1 \mathrm{~g}$ $\mathrm{L}^{-1}$ of myo-inositol and $6 \mathrm{~g} \mathrm{~L}^{-1}$ of agar, according to the protocol established by Nicoloso et al. (2001).

Twenty-five-day-old plantlets from in vitro culture and after $3 \mathrm{~d}$ of acclimatization, following the protocol established by Skrebsky et al. (2006), were transferred into plastic boxes $(10 \mathrm{~L})$ filled with full nutrient solution of low ionic strength under aeration. The nutrient solution contained $\left(\mathrm{mg} \mathrm{L}^{-1}\right)$ : 85.31 of $\mathrm{N} ; 7.54$ of $\mathrm{P} ; 11.54$ of $\mathrm{S} ; 97.64$ of $\mathrm{Ca} ; 23.68$ of $\mathrm{Mg}$; 104.75 of $\mathrm{K} ; 176.76$ of $\mathrm{Cl} ; 0.27$ of $\mathrm{B} ; 0.05$ of $\mathrm{Mo} ; 0.01$ of $\mathrm{Ni}$; 0.13 of $\mathrm{Zn} ; 0.03$ of $\mathrm{Cu} ; 0.11$ of $\mathrm{Mn}$ and 2.68 of $\mathrm{Fe}$. The $\mathrm{pH}$ of the solution was adjusted daily to $5.8 \pm 0.1$ by titration using either $\mathrm{HCl}$ or $\mathrm{NaOH}$ solutions $(0.1 \mathrm{M})$. On the $14^{\text {th }}$ day after transplanting, cadmium $\left(\mathrm{CdCl}_{2} \cdot \mathrm{H}_{2} \mathrm{O}\right)$ was added to each container. In total, five final concentrations were generated: 0 (control), 20, 40, 60 or $80 \mu \mathrm{M}$. The nutrient solution in the growth containers was renewed once a week. Both in vitro and ex vitro cultured plants were grown in a growth chamber at $25 \pm 1^{\circ} \mathrm{C}$ during 16/8-h light/dark cycle with $35 \mu \mathrm{mol} \mathrm{m}{ }^{-2}$ $\mathrm{s}^{-1}$ of irradiance. Cadmium-treated plantlets remained in each solution for $7 \mathrm{~d}$. Three replicates with 54 plantlets were used for each treatment.
Growth analysis: After harvesting, plants were divided into shoots and roots. Roots were rinsed twice using fresh aliquots of distilled water. Subsequently, growth and biochemical parameters were determined. Length of roots was determined according to Tennant (1975), and the length of sprouts was measured with a ruler. To obtain dry weight, the plants were left at $65^{\circ} \mathrm{C}$ until reaching a constant weight.

Cadmium and micronutrient concentrations: Approximately $0.2 \mathrm{~g}$ of roots and shoots were digested with $4 \mathrm{~mL}$ $\mathrm{HNO}_{3}$ using an exposure to high temperature: a) $50^{\circ} \mathrm{C}$ for $1 \mathrm{~h}$; b) $80^{\circ} \mathrm{C}$ for $1 \mathrm{~h}$; and c) $120^{\circ} \mathrm{C}$ for $1 \mathrm{~h}$ in a digester block (Velp, Italy). As a next step, the samples were diluted to $50 \mathrm{~mL}$ with deionized water. Concentrations of $\mathrm{Cd}, \mathrm{Zn}, \mathrm{Mn}, \mathrm{Fe}$, and $\mathrm{Cu}$ were measured by atomic absorption spectroscopy (lyengar et al., 1997).

Acid phosphatase (AP; E.C. 3.1.3.2) activity: Fresh root and shoot extracts were centrifuged at $43200 \mathrm{~g}$ for $30 \mathrm{~min}$ at $4^{\circ} \mathrm{C}$ and the supernatant used for enzyme assay. Acid phosphatase activity was determined according to Tabaldi et al. (2007) using a reaction medium consisting of $3.5 \mathrm{mM}$ sodium azide, $2.5 \mathrm{mM}$ calcium chloride, $100 \mathrm{mM}$ citrate buffer, pH 5.5, in a final volume of $200 \mu \mathrm{L}$. An aliquot of $20 \mu \mathrm{L}$ of the enzyme preparation (10-20 $\mu \mathrm{g}$ protein) was added to the reaction mixture and preincubated for $10 \mathrm{~min}$ at $35^{\circ} \mathrm{C}$. The reaction was started by the addition of substrate and stopped by the addition of $200 \mu \mathrm{L}$ of $10 \%$ trichloroacetic acid (TCA) to a final concentration of $5 \%$. Inorganic phosphate (Pi) was measured at $630 \mathrm{~nm}$ using malachite green as the colorimetric reagent and $\mathrm{KH}_{2} \mathrm{PO}_{4}$ as the standard for the calibration curve. Controls were run to correct for nonenzymatic hydrolysis by adding enzyme preparation after TCA addition. Enzyme specific activities are referred to as nmol Pi released $\mathrm{min}^{-1}$ $\mathrm{mg}^{-1}$ protein. All assays were performed in triplicate using PPi as substrate at a final concentration of $3.0 \mathrm{mM}$.

$\delta$-aminolevulinic acid dehydratase (ALA-D; E.C. 4.2.1.24) activity: Shoot tissue was homogenized in 10 mM Tris- $\mathrm{HCl}$ buffer, pH $9.0(1: 1, \mathrm{w} / \mathrm{v})$. The homogenate was centrifuged at $12000 \mathrm{~g}$ at $4^{\circ} \mathrm{C}$ for 10 min to gain a supernatant ( $\mathrm{S} 1)$ to be used for the enzyme assay. The $\mathrm{S} 1$ was pre-treated with $0.1 \%$ Triton X-100 and $0.5 \mathrm{mM}$ DTT. The ALA-D activity was assayed as described by Barbosa et al. (1998) by measuring the rate of porphobilinogen (PBG) formation. The incubation medium for the assays contained $100 \mathrm{mM}$ Tris-HCl buffer, pH 9.0. For the enzyme assay, 
the final concentration of ALA was $3.6 \mathrm{mM}$. Incubation was started by adding $100 \mu \mathrm{L}$ of the tissue preparation to a final volume of $400 \mu \mathrm{L}$. The product of the reaction was determined with the Ehrlich reagent at $555 \mathrm{~nm}$ using a molar absorption coefficient of $6.1 \times 10^{4} \mathrm{~L} \mathrm{~mol}^{-1} \mathrm{~cm}^{-1}$ (Sassa, 1982) for the Ehrlich-porphobilinogen salt. Activity of ALA-D was expressed as nmol PBG $\mathrm{mg}^{-1}$ protein $\mathrm{h}^{-1}$.

Protein extraction: In all the enzyme preparations, protein was determined by the method of Bradford (1976) using BSA as standard and was expressed in $\mathrm{mg} \mathrm{mL}^{-1}$.

Chlorophyll and carotenoid concentrations: Chlorophyll and carotenoids were extracted using the method of Hiscox and Israelstam (1979) and estimated as described by Arnon (1949). Briefly, chopped fresh shoot sample $(0.1 \mathrm{~g})$ was incubated at $65^{\circ} \mathrm{C}$ in dimethylsulfoxide (DMSO) until tissues were completely bleached. Absorbance of the solution was then measured at 470,645 , and $663 \mathrm{~nm}$ in order to determine the concentrations of carotenoids, chlorophyll a, and chlorophyll b, respectively. Chlorophyll and carotenoid concentrations were expressed as $\mathrm{mg} \mathrm{g}^{-1}$ fresh weight.

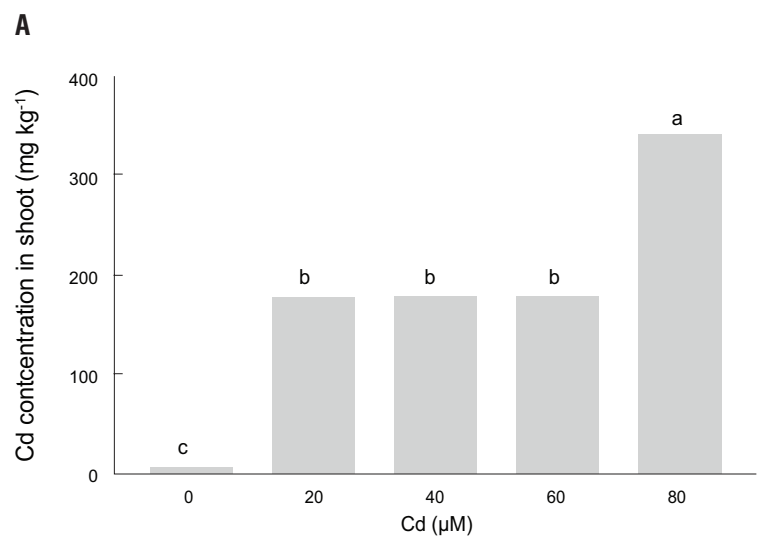

Statistical analysis: The analyses of variance were computed for statistical significance based on F-tests. The results are mean \pm standard deviation of at least three independent replicates. Significance was determined at $P<$ 0.05. The mean differences were compared utilizing Duncan's multiple range tests.

\section{RESULTS}

Cadmium concentration under $\mathrm{Cd}$ exposure: $\mathrm{Cd}$ concentration in both, shoots (Figure 1A) and roots (Figure 1B) increased with increasing Cd levels. External Cd concentrations ranging from 20 to $60 \mu \mathrm{M}$ generated the same enhancement of Cd concentration in both, shoots and roots (36 and 12.5-fold greater than controls, respectively). Cadmium concentration in roots was on average 12-fold greater than in the shoot. The maximum concentration of $\mathrm{Cd}$ in shoot and roots was 345 $\mathrm{mg} \mathrm{kg}^{-1} \mathrm{DW}$ and $3400 \mathrm{mg} \mathrm{kg}^{-1} \mathrm{DW}$, at the $80 \mu \mathrm{M}$ Cd level, respectively.

Figure 1. Cadmium concentration in shoot (A) and roots (B) of Pfaffia glomerata plants grown under increasing concentrations of Cd for $7 \mathrm{~d}$. Values are the mean of three individual replicates. Identical superscripts on bars indicate no significant difference $(P>0.05)$ between means according to Duncan's multiple range test.

Characterisation of Cd tolerance: There was no general pattern of plant growth responses to Cd stress. Number of leaves per plant was slightly, but not significantly, reduced by Cd concentrations up to $40 \mu \mathrm{M}$, whereas at the $80 \mu \mathrm{M}$ Cd level it was reduced by $26 \%$ compared to control plants (Figure 2A). In addition, length of sprouts (Figure 2B) and length of the root system (Figure $2 \mathrm{C}$ ) per plant were not affected by $\mathrm{Cd}$. On the other hand, the root length/shoot length ratio increased significantly at the $20 \mu \mathrm{M}$ Cd level and was slightly, but not significantly, increased after exposure to more than $20 \mu \mathrm{M} \mathrm{Cd}$, as compared to control plants (Figure 2D). 
A

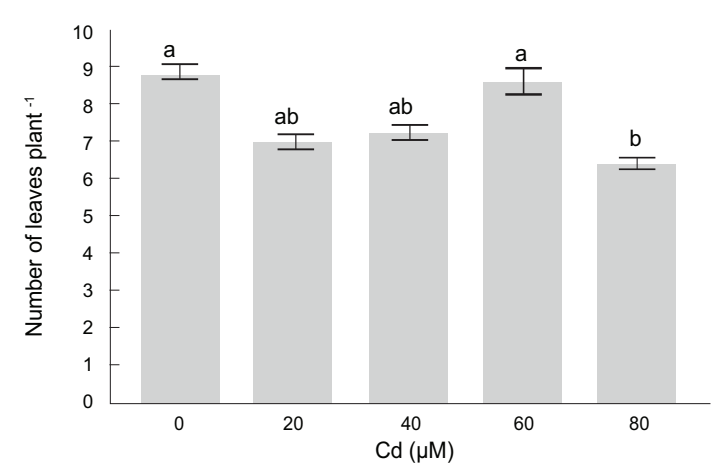

C

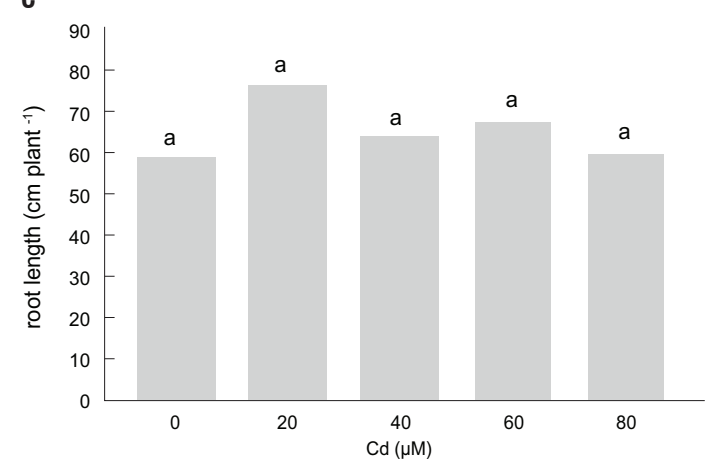

B

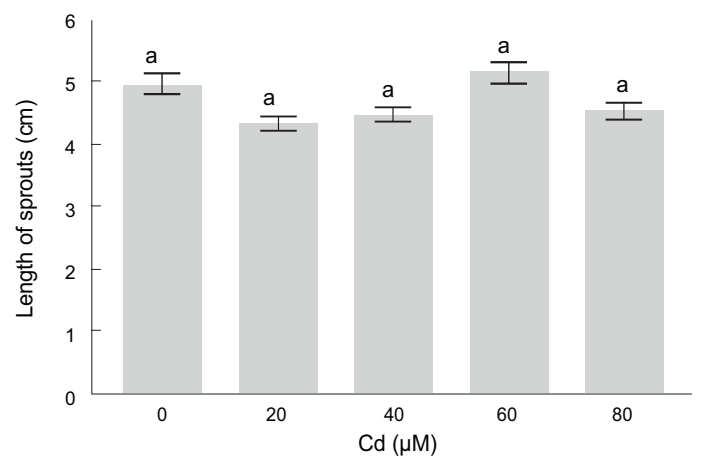

D

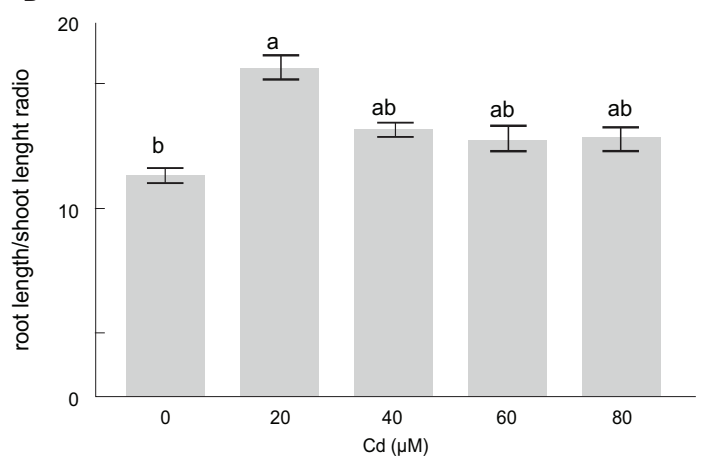

Figure 2. Number of leaves (A), length of sprouts (B), length of whole root system (C), root length/sprout length ratio (D) of Pfaffia glomerata plants grown under increasing concentrations of $\mathrm{Cd}$ for $7 \mathrm{~d}$. Statistics as in Figure 1.

Shoot fresh weight was reduced significantly only upon adding $80 \mu \mathrm{M}$ of $\mathrm{Cd}$ (Figure $3 \mathrm{~A}$ ). In contrast, dry weight of both, shoot (Figure $3 \mathrm{~B}$ ) and roots (Figure $3 \mathrm{C}$ ) increased significantly upon addition of 20 and $40 \mu \mathrm{M} \mathrm{Cd}$. Moreover, shoot and total plant weight were reduced only at the 80 $\mu \mathrm{M}$ Cd level as compared with controls (Figure $3 \mathrm{~B}$ and 3D, respectively). Conversely, root dry weight decreased significantly after exposure to $\mathrm{Cd}$, when the amount exceeded $40 \mu \mathrm{M}$ (Figure 3C).
Effect of $\mathrm{Cd}$ on micronutrient concentrations: A nutrientand organ-dependent response to Cd toxicity was observed (Table 1). Zinc remained unaltered after applying $\mathrm{Cd}$ treatments. In roots however, Mn concentration was reduced significantly independent of the $\mathrm{Cd}$ levels added, Fe concentration increased significantly upon addition of 20 and $80 \mu \mathrm{M} \mathrm{Cd}$, whereas $\mathrm{Zn}$ and $\mathrm{Cu}$ levels did not respond to the treatments.

Table 1. Concentrations of $\mathrm{Zn}, \mathrm{Mn}$, Fe and $\mathrm{Cu}$ in shoot and roots of Pfaffia glomerata plants grown under increasing concentrations of Cd for $7 \mathrm{~d}$. Values are the mean of three individual replicates. Means in columns for each plant tissue followed by the same letter did not differ significantly $(P>0.05)$ from each other according to Duncan's multiple range test.

\begin{tabular}{|c|c|c|c|c|c|c|c|c|}
\hline \multirow{3}{*}{$\begin{array}{l}\text { Treatments } \\
\mathrm{Cd}(\mu \mathrm{M})\end{array}$} & \multicolumn{8}{|c|}{ Micronutrient concentration } \\
\hline & \multicolumn{2}{|c|}{ Zn (mg kg-1 dw) } & \multicolumn{2}{|c|}{ Mn (mg kg-1 dw) } & \multicolumn{2}{|c|}{$\mathrm{Fe}(\mathrm{mg} \mathrm{kg}-1 \mathrm{dw})$} & \multicolumn{2}{|c|}{$\mathrm{Cu}(\mathrm{mg} \mathrm{kg}-1 \mathrm{dw})$} \\
\hline & Root & Shoot & Root & Shoot & Root & Shoot & Root & Shoot \\
\hline 0 & $719 a$ & $128 \mathrm{a}$ & $508 a$ & $140 a$ & $18209 b$ & $265 a$ & $79 a$ & $16 a$ \\
\hline 20 & $573 a$ & $148 a$ & $168 \mathrm{c}$ & $121 a$ & $24821 a$ & $395 a$ & $126 a$ & $14 a$ \\
\hline 40 & $523 a$ & $91 \mathrm{a}$ & $177 c$ & $118 \mathrm{a}$ & $19539 b$ & $308 a$ & $93 a$ & $15 a$ \\
\hline 60 & $571 a$ & $105 a$ & $244 b c$ & $99 a$ & $19320 b$ & $306 a$ & $90 \mathrm{a}$ & $16 a$ \\
\hline 80 & $650 a$ & $104 a$ & $322 \mathrm{~b}$ & $114 a$ & $21663 a$ & $411 \mathrm{a}$ & $85 a$ & $14 \mathrm{a}$ \\
\hline CV (\%) & 20.0 & 32.6 & 18.9 & 18.6 & 14.7 & 28.6 & 15.2 & 21.0 \\
\hline
\end{tabular}


A

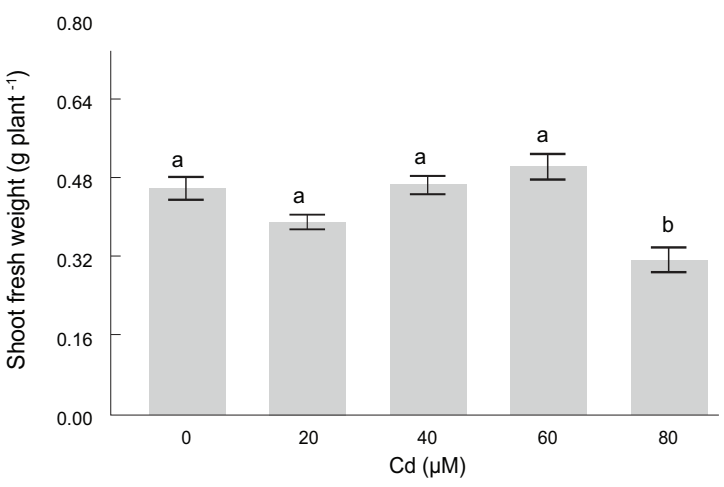

C

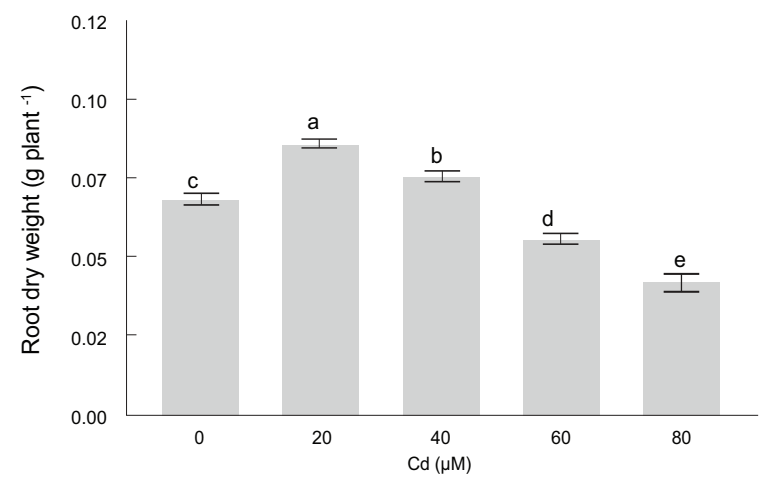

B

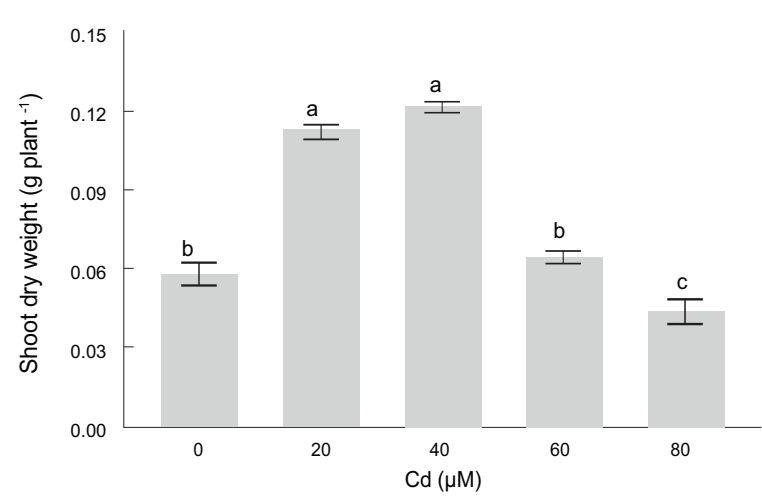

D

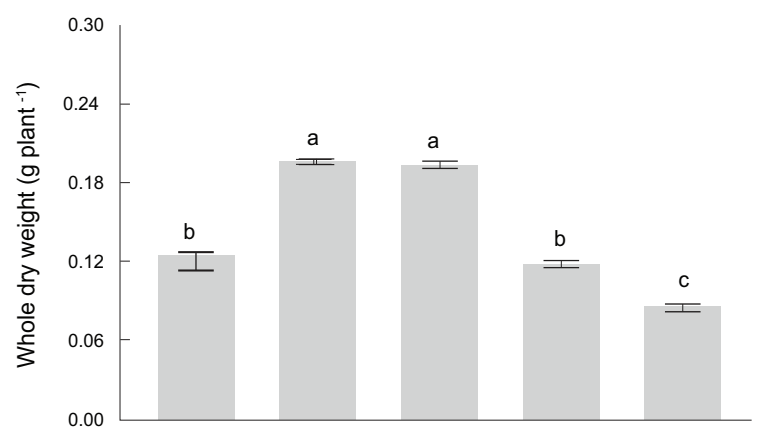

Figure 3. Shoot fresh weight (A), shoot dry weight (B), root dry weight (C), and whole plant dry weight (D) of Pfaffia glomerata plants grown under increasing concentrations of $\mathrm{Cd}$ for $7 \mathrm{~d}$. Statistics as in Figure 1.

Acid phosphatase activity (AP): Acid phosphatase activity was reduced in shoot (23\%) and roots $(30 \%)$ with increasing Cd levels. No difference in AP activity in both, shoot and roots was found for $\mathrm{Cd}$ treatments ranging from 20 to 80 $\mu \mathrm{M}$ (Figure 4).

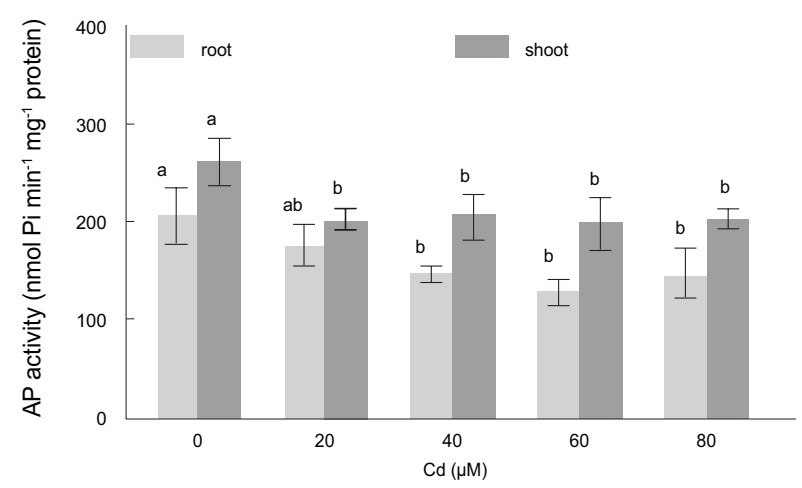

Figure 4. Acid phosphatase activities in shoot and roots of Pfaffia glomerata plants grown under increasing concentrations of Cd for $7 \mathrm{~d}$. Statistics as in Figure 1. 
ALA-D activity and concentrations of chlorophyll and carotenoids: Shoot ALA-D activity decreased with increasing $\mathrm{Cd}$ levels in the nutrient solution (Figure $5 \mathrm{~A}$ ). A maximum of $89 \%$ depletion in ALA-D activity was found at $80 \mu \mathrm{M} \mathrm{Cd}$. Total chlorophylls were also reduced but only at the 20 and $80 \mu \mathrm{M}$ Cd levels (Figure 5B). On the other hand, carotenoid concentration was significantly reduced upon addition of 20 , 60 and $80 \mu \mathrm{M} \mathrm{Cd}$ (Figure 5C).

\section{A}

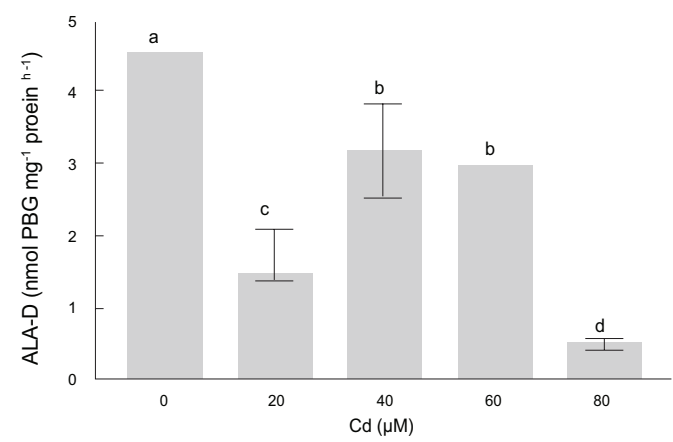

B

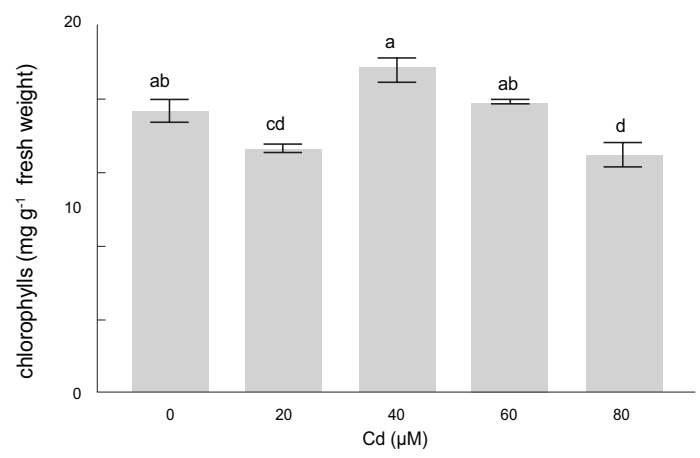

C

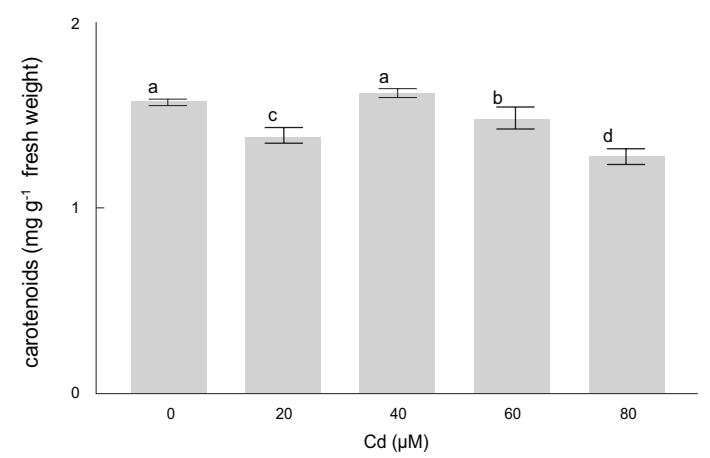

Figure 5. Activity of $\delta$-aminolevulinic acid dehydratase (ALA-D) (A), chlorophyll (B) and carotenoid concentration (C) of Pfaffia glomerata plants grown under increasing concentrations of $\mathrm{Cd}$ for $7 \mathrm{~d}$. Statistics as in Figure 1.

\section{DISCUSSION}

Cadmium concentration and plant tolerance to Cd: Our data (Figure 1) demonstrate that higher metal exposures led to remarkable $\mathrm{Cd}$ accumulation in both, root and shoot tissues, resulting in a high degree of toxicity as also by other authors (e.g., Carneiro et al., 2002; Lima et al., 2006; Mishra et al. 2006). Meanwhile, no significant difference in both shoot and root $\mathrm{Cd}$ concentrations was found between the 20 to 60 $\mu \mathrm{M}$ Cd treatments. We also checked Cd concentration in the nutrient solution at day 0 and $7 \mathrm{~d}$ after applying the treatments: external $\mathrm{Cd}$ was not significantly depleted during the experiment (data not shown). These data suggest that, up to a certain level of metal concentration, roots of $P$. glomerata have some mechanism to avoid excess of $\mathrm{Cd}$ uptake. Cadmium confinement in the root tissues may be due to an efficient binding and sequestration to the vacuoles by glutathione and phytochelatins, or by imobilization of $\mathrm{Cd}$ by the cell wall and extracellular carbohydrates (Lima et al., 2006; Mishra et al., 2006, Almeida et al., 2007).

Our data indicate, that the root length/shoot length ratio increased after treatment with all studied $\mathrm{Cd}$ concentrations (Figure 2D), which is not consistent with the results of Guo and Marschner (1995), who reported that usually the inhibition of root elongation of different plant species is the most sensitive parameter of $\mathrm{Cd}$ toxicity. In addition, our results also indicate that root elongation was much less affected than the decrease in biomass, which is not consistent with the earlier results of Lima et al. (2006) for Pisum sativum and of Meuwly and Rauser (1992) for Zea mays. According to Meuwly and Rauser (1992), since most of the root elongation is located in the first $10 \mathrm{~mm}$ of the root apex, the contribution of the biomass to this portion is probably too small to allow the detection of any toxic symptoms during the first days, but length inhibitions are enough to be detected. Therefore, since root biomass of $P$. glomerata was significantly reduced upon addition of $\mathrm{Cd}$ levels exceeding $40 \mu \mathrm{M}$, the data indicate, that $P$. glomerata has some degree of $\mathrm{Cd}$ tolerance. Meanwhile, there was an increase in both, root and shoot biomass (Figure 3) at lower Cd levels (20 and $40 \mu \mathrm{M})$. It should be emphasized that experiments of the present study were carried out three times (with some modifications), and results were almost the same for most parameters analyzed including the increased biomass we found (data not shown). The positive effects of low levels 
of $\mathrm{Cd}$ on plant growth have been poorly discussed in the literature, and the mechanisms are not well understood. This phenomenon is normally related to a so-called hormetic effect that probably represents an "overcompensation" response to a disruption in the homeostasis of the organism (Aina et al., 2007). Khan et al. (2008) observed similar phenomena in sand culture where $10 \mu \mathrm{M} \mathrm{Cd}$ enhanced the activities of leaf superoxide dismutase, ascorbate peroxidase, glutathione reductase and carbonic anhydrase, net photosynthetic rate and plant dry mass of Triticum aestivum at low Zn level. These authors suggested that the synergies among the activities of antioxidative enzymes helped to maintain carbonic anhydrase and thus photosynthesis and plant biomass at low $\mathrm{Cd}$ levels under low $\mathrm{Zn}$ concentration. Taking into account the fact that the total dry biomass of P. glomerata was only significantly reduced at the $80 \mu \mathrm{M}$ $\mathrm{Cd}$ level and such a concentration is within that observed in highly polluted soils, these results further indicate that $P$. glomerata seems to have some degree of $\mathrm{Cd}$ tolerance, as was found for an undetermined species belonging to the genus Pfaffia, reported by Carneiro et al. (2002). However, additional experiments should be performed in order to allow a better understanding of the mechanism of the effect of $\mathrm{Cd}$ toxicity on growth, photosynthesis and antioxidative mechanisms of $P$. glomerata.

Nutrients concentration under different degrees of $\mathrm{Cd}$ stress: It is well known that many toxic effects of $\mathrm{Cd}$ action result from interaction with micronutrients, in particular those with the same valence as $\mathrm{Cd}$, such as $\mathrm{Zn}, \mathrm{Mn}, \mathrm{Fe}$, and $\mathrm{Cu}$. Our results showed that $\mathrm{Zn}$ and $\mathrm{Cu}$ concentrations in both shoot and roots remained unaltered upon $\mathrm{Cd}$ addition. Both synergistic and antagonistic effects of $\mathrm{Cd}$ on $\mathrm{Zn}$ and $\mathrm{Cu}$ were found in other studies (Jiang et al., 2004; Dong et al., 2006). Our data indicate that Mn uptake was affected by $\mathrm{Cd}$ stress but not the translocation of $\mathrm{Mn}$ within $P$. glomerata plants. An inhibition in $\mathrm{Mn}$ uptake and transport by $\mathrm{Cd}$ has been reported by Dong et al. (2006) for Lycopersicon esculentum. In contrast, an increase in Mn uptake and translocation to the shoots was observed in Lactuca sp. exposed to $\mathrm{Cd}$ stress and there was a higher $\mathrm{Mn}$ accumulation in chloroplasts when $\mathrm{Cd}$ was present in the growth medium (Ramos et al., 2002). Some studies showed that there is an antagonistic relationship between $\mathrm{Cd}$ and Fe (Sharma et al., 2004). Arabidopsis plants that overexpressed the IRT1 gene, a major transporter responsible for high-affinity iron uptake from the soil, accumulated higher levels of $\mathrm{Cd}$ and $\mathrm{Zn}$ than the wild type, indicating that IRT1 is responsible for the uptake of these metals (Connolly et al., 2002). Our data demonstrate that a synergistic effect of $\mathrm{Cd}$ on Fe concentration in root at the 20 and $80 \mu \mathrm{M} \mathrm{Cd}$ concentrations is likely to occur. Some of these conflicting results found in our study in relation to others might be presumably due to the differences in the culture methods, species, as well as growth conditions including $\mathrm{Cd}$ and micronutrient levels in medium, growth period, temperature and light.

Metabolic enzymes, and concentration of chlorophyll and carotenoid in different degrees of $\mathrm{Cd}$ stress: Our results showed that under Cd stress, AP activity in both shoot and roots was similarly reduced regardless of the amount of $\mathrm{Cd}$ added. Conversely, Tabaldi et al. (2007) found that Cd, Mn and Na did not significantly alter the AP activity in Cucumis sativus. Phosphatases are generally metalloenzymes depending on $\mathrm{Ca}^{2+}$ or $\mathrm{Mg}^{2+}$. A possible mechanism explaining Cd-toxicity at high concentrations can be the replacement of $\mathrm{Ca}^{2+}$ and $\mathrm{Mg}^{2+}$ by $\mathrm{Cd}$ in the active site of enzyme, or the $\mathrm{Cd}$ can be interfering with the $\mathrm{PO}_{4}{ }^{3-}$ binding sites. Other metals such as $\mathrm{Hg}$ and $\mathrm{Zn}$ also inhibited AP activity of cucumber, possibly through this mechanism (Tabaldi et al., 2007). Therefore, inhibition of AP activity in $P$. glomerata caused by $\mathrm{Cd}$ stress may impair phosphate mobilization, since this enzyme is involved in $\mathrm{P}$ metabolism, an essential element for plant growth and development (Duff et al., 1994).

Altered ALA-D activity concomitantly with reduced chlorophyll contents has been reported in many terrestrial plants exposed to various metals (Pereira et al., 2006). Our data also showed that total chlorophyll concentration was reduced significantly at 20 and $80 \mu \mathrm{M} \mathrm{Cd}$ (Figure 5B), at which greater reduction in ALA-D activity was observed. Moreover, there was a significant positive correlation $\left(r^{2}=0.73\right)$ between concentrations of carotenoids and chlorophylls. Carotenoids play a pivotal role in photoprotection of chlorophylls against photooxidative damage by quenching reactive oxygen species (ROS) such as singlet oxygen (Behera et al., 2002). Similarly, other authors have found a decrease in carotenoid content in Cd-treated plants, which might be interpreted as an overproduction of ROS (Mishra et al., 2006). In addition, ALA-D inhibition could have led to ALA accumulation that within the cell might contribute to enhance ROS production (Noriega et al., 2006). Therefore, in future studies it will be 
necessary to analyze the effects of Cd on ROS formation and on both enzymatic and non-enzymatic antioxidant systems. These defence systems can remove, neutralise or scavenge oxy-radicals and their intermediates (Gratão et al., 2005).

Acknowledgements: The authors wish to thank the Conselho Nacional de Desenvolvimento Científico e Tecnológico (CNPq), Coordenação e Aperfeiçoamento de Pessoal de Nível Superior (CAPES) and Fundação de Amparo à Pesquisa do Estado do Rio Grande do Sul (FAPERGS) for the research fellowships.

\section{REFERENCES}

Aina R, Labra M, Fumagalli P, Vannini C, Marsoni M (2007) Thiol-peptide level and proteomic changes in response to cadmium toxicity in Oryza sativa L. roots. Environ. Exp. Bot. 59:381-392.

Almeida AF, Valle RR, Mielke MS, Gomes FP (2007) Tolerance and prospection of phytoremediator woody species of $\mathrm{Cd}, \mathrm{Pb}, \mathrm{Cu}$ and $\mathrm{Cr}$. Braz. J. Plant Physiol. 19:83-98.

Arnon DI (1949) Copper enzymes in isolated chloroplasts: polyphenoloxidase in Beta vulgaris. Plant. Physiol. 24:1-15.

Barbosa NVB, Rocha JBT, Zeni G, Emanuelli T, Beque MC, Braga AL (1998) Effect of organic forms of selenium on $\delta$-aminolevulinate dehydratase from liver, kidney and brain of adult rats. Toxicol. Appl. Pharmacol. 149:243-253.

Behera RK, Mishra PC, Choudhury NK (2002) High irradiance and water stress induce alterations in pigment composition and chloroplast activities of primary wheat leaves. J. Plant Physiol. 159:967-973.

Bradford MM (1976) A rapid and sensitive method for the quantitation of microgram quantity of protein utilizing the principle of protein-dye binding. Anal. Biochem. 72:248-254.

Boussama N, Quariti 0, Ghorbal MH (1999) Changes in growth and nitrogen assimilation in barley seedlings under cadmium stress. J. Plant Nutr. 22:731-752.

Carneiro MAC, Siqueira J0, Moreira FMS (2002) Comportamento de espécies herbáceas em misturas de solo com diferentes graus de contaminação com metais pesados. Pesq. Agropec. Bras. 37:1629-1638.

Connolly EL, Fett JP, Guerinot ML (2002) Expression of the IRT1 metal transporter is controlled by metals at the levels of transcript and protein accumulation. Plant Cell. 14:1347-1357.

Dong J, Wu F, Zhang G (2006) Influence of cadmium on antioxidant capacity and four microelement concentrations in tomato seedlings (Lycopersicon esculentum). Chemosphere. 64:1659-1666.

Duff SMG, Sarath G, Plaxton WC (1994) The role of acid phosphatase in plant phosphorus metabolism. Physiol. Plant. 90:791-800.

Fodor E, Szabó-Nagy A, Erdei L (1995) The effects of cadmium on the fluidity and $\mathrm{H}^{+}$-ATPase activity of plasma membrane from sunflower and wheat roots. J. Plant Physiol. 147:87-92.

Gallego SM, Benavides MP, Tomaro ML (1996) Oxidative damage caused by cadmium chloride in sunflower (Helianthus annuus, L.) plants. Phyton - Int. J. Exp. Bot. 58: 41-52.

Gratão PL, Polle A, Lea PJ, Azevedo RA (2005) Making the life of heavy metalstressed plants a little easier. Funct. Plant Biol. 32:481-494.
Guo YT, Marschner H (1995) Uptake, distribution, and binding of cadmium and nickel in different plant species. J. Plant Nutr. 18:2691-2706.

lyengar GV, Subramanian KS, Woittiez JRW (1997) Elemental Analysis of Biological Samples. Principles and Practice. CRC Press, Boca Raton.

Hadjiliadis ND (1997) Cytotoxic, mutagenic and carcinogenic potential of heavy metals related to human environment. Kluwer Academic, Norwell.

Hiscox JD, Israelstam GF (1979) A method for the extraction of chlorophyll from leaf tissue without maceration. Can. J. Bot. 57:1132-1334.

Khan NA, Singh S, Anjum NA, Nazar R (2008) Cadmium effects on carbonic anhydrase, photosynthesis, dry mass and antioxidative enzymes in wheat (Triticum aestivum) under low and sufficient Zn. J. Plant Interact. 3:31-37.

Jaffe EK, Kervinen J, Dunbrack J, Litwin S, Martins J, Scarrow RC, Volin M, Yeung AT, Yonn E (2000) Porphobilinogen synthase from pea: expression from an artificial gene, kinetic characterization, and novel implications for subunit interactions. Biochemistry. 39:9018-9029.

Jiang XJ, Luo YM, Liu Q, Liu SL, Zhao QG (2004) Effects of cadmium on nutrient uptake and translocation by Indian Mustard. Environ. Geochem. Health. 26:319-324.

Lima AIG, Pereira SIA, Figueira EMAP, Caldeira GCN, Caldeira HDQM (2006) Cadmium detoxification in roots of Pisum sativum seedlings: relationship between toxicity levels, thiol pool alterations and growth. Environ. Exp. Bot. 55:149-162.

Meuwly P, Rauser WE (1992) Alteration of thiol pools in roots and shoots of maize seedlings exposed to cadmium: adaptation and developing cost. Plant Physiol. 99:8-15.

Mishra S, Srivastava S, Tripathi RD, Govindarajan R, Kuriakose SV, Prasad MNV (2006) Phytochelatin synthesis and response of antioxidants during cadmium stress in Bacopa monnieri L. Plant Physiol. Biochem. 44:25-37.

Montanari IJr, Magalhães PM, Queiroga CL (1999) Influence of plantation density and cultivation cycle on root produtivity and tenors of $\beta$-ecdysone in Pfaffia glomerata (Spreng.) Pedersen. Acta Hort.502:125-128.

Murashige T, Skoog F (1962) A revised medium for rapid growth and bioassays with tobacco tissue cultures. Physiol. Plant. 15:473-497.

Nicoloso FT, Erig AC, Martins CF, Russowski D (2001) Micropropagação do Ginseng brasileiro [Pfaffia glomerata (Spreng.) Pedersen]. Rev. Bras. PI. Med. 3:11-18.

Noriega GO, Balestrasse KB, Batlle A, Tomaro MA (2007) Cadmium induced oxidative stress in soybean plants also by the accumulation of $\delta$-aminolevulinic acid. Biometals. 20:841-851.

Pauza NL, Cotti MJP, Godar L, Sancovich AMF, Sancovith HA (2005) Disturbances on delta aminolevulinate dehydratase (ALA-D) enzyme activity by $\mathrm{Pb}^{2+}, \mathrm{Cd}^{2+}, \mathrm{Cu}^{2+}, \mathrm{Mg}^{2+}, \mathrm{Zn}^{2+}, \mathrm{Na}^{+}$and $\mathrm{Li}^{+}$: analysis based on coordination geometry and acid-base Lewis capacity. J. Inorg. Biochem. 99:409-414.

Penheiter AR, Duff SMG, Sarath G (1997) Soybean root nodule acid phosphatase. Plant Physiol. 114:597-604.

Pereira LB, Tabaldi LA, Gonçalves JF, Jucoski GO, Pauletto MM, Weis SN, Nicoloso FT, Borher D, Rocha JBT, Schetinger MRC (2006) Effect of aluminum on $\delta$-aminolevulinic acid dehydratase (ALA-D) and the development of cucumber (Cucumis sativus). Environ. Exp. Bot. 57:106-115.

Ramos I, Esteban E, Lucena JJ, Gárate A (2002) Cadmium uptake and subcellular distribution in plants of Lactuca sp. Cd-Mn interaction. Plant Sci. 162:761-767.

SassaS (1982) $\delta$-Aminolevulinic aciddehydrataseassay. Enzyme. 28:133-145.

Sharma SS, Kaul S, Metwally A, Goyal K, Finkemeier I, Dietz KJ (2004) Cadmium toxicity to barley (Hordeum vulgare) as affected by varying Fe nutritional status. Plant Sci. 166:1287-1295.

Skrebsky EC, Nicoloso FT, Maldaner J (2006) Substratos na aclimatização de Pfaffia glomerata (Spreng.) Pedersen produzida in vitro sob diferentes doses de sacarose. C. Rural. 36:1416-1423. 
Tabaldi LA, Ruppenthal R, Cargnelutti D, Morsh VM, Pereira LB, Schetinger MRC (2007) Effects of metal elements on acid phosphatase activity in cucumber (Cucumis sativus L.) seedlings. Environ. Exp. Bot. 59:43-48.

Taniguchi SF, Bersani-Amado CA, Sudo LS, Assef SMC, Oga S (1997) Effect of Pfaffia iresinoides on the experimental inflammatory process in rats. Phytother. Res. 11:568-571.
Tennant D (1975) A test of a modified line intersect method of estimating root length. J. Ecol. 63:995-1001.

Verma S, Dubey RS (2001) Effect of cadmium on soluble sugars and enzymes of their metabolism in rice. Biol. Plant. 44:117-123. 